\title{
Eksistensi Perhimpunan Pemilik dan Penghuni Satuan Rumah Susun (PPPSRS) dalam Kewenangan Pengelolaan Rumah Susun Sewa
}

\author{
Nuraini Zachman ${ }^{1 *}$, Nur Fauzia ${ }^{2}$ \\ ${ }^{1}$ Magister Hukum, Universitas Batanghari Jambi \\ ${ }^{2}$ Fakultas Hukum Universitas Batanghari \\ Jalan Slamet Riyadi Broni Kota Jambi Telp: (0741) 65351 \\ *Correspondence email: nuraini.zachman@unbari.ac.id, nur.fauzia@unbari.ac.id
}

\begin{abstract}
Abstrak. Rumah susun merupakan respon terhadap kebutuhan rumah bagi masyarakat dan menjadi alternatif pilihan untuk penyediaan hunian yang ideal bagi negara-negara berkembang. tujuan dalam penelitian dan penulisan karya ilmiah ini melalui metode pendekatan normatif adalah menganalisis Kegiatan Pengelolaan Rumah Susun oleh Badan Pengelola, eksistensi Perhimpunan Pemilik dan Penghuni Satuan Rumah Susun (PPPSRS), Hak Suara Berkaitan dengan Kewenangan Pengelolaan dan Pengelolaan Rumah Susun Sewa dibandingkan dengan Pengelolaan Rumah Susun Komersial. Di dalam penelitian ini menggunakan pendekatan yuridis empiris karena peneliti dilakukan secara langsung terhadap pengelola rumah susun sewa. Ruang lingkup dalam penelitian ini adalah pengelolaan rumah susun dan objeknya adalah rumah susun di daerah perkotaan. Bahan yang digunakan yaitu bahan lapangan dan bahan kepustakaan. Teknik pengumpulan data yaitu studi dokumen dan teknik analisis adalah analisis kualitatif. Kegiatan pengelolaan rumah susun wajib pengelolanya berbadan hukum yaitu Himpunan Pemilik dan Penghuni Satuan Rumah Susun yang dibuat akta yang sah oleh Bupati atau Walikotamadya Kepala Daerah Tingkat II dan penentuan hak suara anggota ini belum terwujud sepenuhnya. Pengelolaan rumah susun sederhana sewa dibutuhkan Unit Pengelolaan Teknis (UPT) sedangkan Pengelolaan Rumah Susun Komersial adalah Badan Pengelola Rumah Susun Komersial adalah Perhimpunan Pemilik dan Penghuni Satuan Rumah Susun, developer sebagai Badan Pengelola sementara.
\end{abstract}

Kata Kunci: Perhimpunan, Rumah Susun, Kewenangan, Pengelolaan

\begin{abstract}
Flats are a response to the needs of housing for the community and become an alternative choice for providing ideal housing for developing countries. The purpose of research and writing of this scientific paper through the normative approach method is to analyze the Activities of Management of Flats by the Management Agency, the existence of the Association of Owners and Occupants of Apartment Units (PPPSRS), Voting Rights Related to the Authority of Management and Management of Rental Flats compared to Management of Flats Commercial. In this study using an empirical juridical approach because the researcher was carried out directly on the manager of the rental apartment. The scope of this research is the management of flats and its objects are flats in urban areas. The materials used are field materials and library materials. The data collection technique is document study and the analysis technique is qualitative analysis. The activity of managing the apartment is obliged to be the manager of a legal entity, namely the Association of Owners and Residents of Apartment Units which have been made a legal deed by the Regent or Mayor of the Level II Region and the determination of the voting rights of these members has not been fully realized. Management of simple rental apartments is required by Technical Management Unit (UPT), while Management of Commercial Flats is the Management Body of Commercial Flats, which is the Association of Owners and Occupants of Flat Units, developer as a temporary Management Agency.
\end{abstract}

Keywords: Association, Flats, Authority, Management

\section{PENDAHULUAN}

Sekarang ini kepadatan penduduk semakin hari semakin meningkat seiring dengan perkembangan dan kemajuan teknologi di dalam masyarakat. Dengan kepadatan penduduk yang sekarang ini terus meningkat maka dibutuhkan adanya rumah susun guna untuk memberi kenyamanan dan perlindungan terhadap seluruh masyarakat. Oleh karena itu, pembangunan terkait rumah susun sangat dibutuhkan untuk mengatasi permasalahan terutama di kawasan kumuh. Selain melakukan pembangunan juga harus menyediakan tanah bagi hunian guna untuk memperlancar pembangunan rumah susun tersebut. Dalam setiap melakukan perbaikan di kawasan kumuh seluas 1 hektar biasanya dapat mengatasi kawasan kumuh seluas 4 hektar. Program seperti ini menjadi penting di perkotaan karena mengingat pada tahun 2030 sekitar 70\% penduduk Indonesia akan menempati di kawasan perkotaan sehingga membutuhkan rumah susun untuk mengatasi kepadatan penduduk yang tinggal di perkotaan.

Sebenarnya dengan ada pembangunan rumah susun ini di daerah kawasan kota-kota besar akan dapat mengatasi permasalahan terkait dengan transportasi yang padat di daerah perkotaan karena Apabila tempat tinggal masyarakat dekat dengan kawasan atau lokasi kerja kerja mereka Maka tidak menutup kemungkinan selain mengurangi kepadatan transportasi di daerah perkotaan, juga meminimalisir tingkat pengeluaran untuk ongkos transportasi dalam masyarakat. Dengan adanya rumah susun ini sebenarnya selain mengatasi terkait dengan kepadatan penduduk juga mengatasi pengurangan penggunaan transportasi di daerah perkotaan. Kondisi yang demikian ini tentunya diperlukan adanya kerjasama antara pemerintah pusat dan daerah dalam memantau tata ruang daerah perkotaan dan transportasi. 
Adanya pembangunan rumah susun ini merupakan reaksi dari masyarakat terkait dengan kebutuhan tempat tinggal sehingga dengan adanya pembangunan rumah susun ini akan menjadi alternatif bagi masyarakat yang kelas bawah untuk mendapatkan rumah hunian sesuai dengan kebutuhan dan pendapatan masyarakat itu sendiri. Oleh karena itu, sebenarnya keberadaan rumah susun menjadi alternatif di negara-negara berkembang seperti Indonesia saat ini karena mengingat kepadatan penduduk dan persediaan tanah tidak seimbang sehingga dibutuhkan solusi dalam mengatasi hal tersebut. Untuk itu, dalam mengatasi permasalahan tersebut maka dibutuhkan suatu konsep dalam pembangunan terkait dengan kesediaan hunian serta kelayakan hunian untuk masyarakat yang membutuhkan tempat tinggal di daerah perkotaan.

Pada prakteknya pembangunan Rumah Susun yang marak berkembang saat ini diselenggarakan oleh pihak Swasta, belum seideal tujuannya, para pengembang atau developer lebih mementingkan segi keuntungannya daripada tujuan untuk memenuhi kebutuhan rakyat yang berpenghasilan menengah ke bawah yang dalam Undang Undang Nomor 20 Tahun 2011 disebut MBR (Masyarakat Berpenghasilan Rendah). Apabila dilihat dalam undang-undang tersebut maka yang menjadi sasaran utama adalah masyarakat yang berpenghasilan rendah sehingga undang-undang tersebut dikeluarkan untuk menyesuaikan kebutuhan masyarakat dalam memiliki rumah susun, dimana masyarakat tersebut memiliki penghasilan yang rendah. Namun, pada kenyataannya di lapangan berbeda dengan tujuan dalam undang-undang yang telah diberlakukan di masyarakat sehingga Pembangunan rumah susun untuk sekarang ini disasarkan kepada masyarakat yang memiliki penghasilan ke atas.

Selanjutnya Setiap Rumah Susun/Apartemen wajib mempunyai Perhimpunan Penghuni yang disebut PPPSRS, PPPSRS ini bertugas untuk membentuk dan melakukan pengawasan terhadap Badan Pengelola Rumah Susun. Selain itu juga, PPPSRS berkewenangan dalam memberikan asuransi Apartemen apabila dikemudian hari terjadi kebakaran di daerah rumah susun tersebut. Sebenarnya PPPSRS ini dibuat sesuai dengan tujuannya yaitu untuk ketertiban, menimbulkan rasa gotong-royong dan keselarasan sesuai dengan prinsip dasar bangsa Indonesia sehingga dalam hal ini untuk pengelolaannya berprinsip bagian bersama, benda dan tanah bersama Sesuai dengan kegiatan yang ada di Rukun Tetangga (RT) dan Rukun Warga (RW) yang bergerak di kemasyarakatan. Dimana lembaga RT dan RW ini sebenarnya dipilih oleh masyarakat daerah itu sendiri.

Namun, di sisi lain peran dan fungsi PPPSRS Untuk sekarang ini menjadi tidak efektif apabila developer masih bertahan di Apartemen. Hal yang demikian ini biasanya disebabkan karena satuan rumah susun dalam penjualnya belum habis dan terkadang juga sebagiannya digunakan oleh developer itu sendiri. Tidak hanya itu saja, terkadang ada juga sebagian rumah susun disewakan sehingga dalam hal ini developer juga masih memiliki kepentingan yang besar atas rumah susun/ apartemen yang dibangun, bahkan terhadap masalah penyelenggaraan pengelolaan rumah susun tersebut masih berpotensi mengakibatkan pertentangan kepentingan antara dua belah pihak. Seharusnya pengelolaan diurus dan diserahkan kepada PPPSRS sebagaimana yang telah diatur dalam Pasal 74, Pasal 75, Pasal 76, dan Pasal 77 Undang-Undang Nomor 20 Tahun 2011 tersebut, yang diatur dengan Peraturan Pemerintah sesuai dengan ketentuan Pasal 78 Undang-Undang Nomor 20 Tahun 2011.

Kegiatan yang dilakukan pihak Pengelola dan badan pengelola yang ditunjuk Developer pada rumah susun komersial sebagian besar berjalan lancar, namun sebagian besar yang lain ada dalam pusaran konflik antara Badan Pengelola dengan PPPSRS, kekalahan ada dipihak yang lemah yaitu PPPSRS, dan Penegak hukum tidak mau dipersalahkan karena bagaimana mereka bisa menerapkan dan menegakkan aturan hukum jika tidak ada kepastian hukum.

Berdasarkan penjelasan diatas maka peneliti membuat batasan permasalahan sehingga mempermudah peneliti dalam menjelaskan permasalahan yang sedang diteliti. Oleh karena itu, batasan penelitian dalam hal ini yaitu bagaimana kegiatan Pengelolaan Rumah Susun oleh Badan Pengelola, bagaimana eksistensi Perhimpunan Pemilik dan Penghuni Satuan Rumah Susun (PPPSRS), bagaimana hak Suara Berkaitan dengan Kewenangan Pengelolaan dan Pengelolaan Rumah Susun Sewa dibandingkan dengan Pengelolaan Rumah Susun Komersial sehingga tujuan dalam penelitian dan penulisan karya ilmiah ini melalui metode pendekatan normatif adalah menganalisis Kegiatan Pengelolaan Rumah Susun oleh Badan Pengelola, eksistensi Perhimpunan Pemilik dan Penghuni Satuan Rumah Susun (PPPSRS), Hak Suara Berkaitan dengan Kewenangan Pengelolaan dan Pengelolaan Rumah Susun Sewa dibandingkan dengan Pengelolaan Rumah Susun Komersial.

\section{METODE}

Di dalam penelitian ini menggunakan pendekatan yuridis empiris karena peneliti dilakukan secara langsung terhadap pengelola rumah susun sewa. Selain meneliti secara langsung di lapangan, peneliti juga terlebih dahulu melihat peraturan perundang-undangan terkait dengan kewenangan Perhimpunan Pemilik Dan Penghuni Satuan Rumah Susun. Ruang lingkup dalam penelitian ini adalah terkait dengan pengelolaan rumah susun dan objek yang dikaji adalah rumah susun di daerah perkotaan.

Bahan yang digunakan dalam penelitian ini yaitu bahan lapangan berupa data-data yang ada lapangan terkait dengan pengelolaan rumah susun dan bahan kepustakaan yang berkaitan dengan permasalahan kewenangan 
Perhimpunan Pemilik Dan Penghuni Satuan Rumah Susun. Kemudian teknik pengumpulan data yang digunakan dalam penelitian ini yaitu studi dokumen, di mana studi dokumen ini mengkaji terkait dokumen yang sedang diteliti oleh peneliti yaitu tentang Perhimpunan Pemilik Dan Penghuni Satuan Rumah Susun (PPPSRS) dalam kewenangan pengelolaan rumah susun sewa. Selanjutnya teknik analisis yang digunakan adalah analisis kualitatif, dimana analisis kualitatif ini menceritakan tentang permasalahan yang sedang diteliti dan dituangkan secara tersusun di dalam pembahasan penelitian ini.

\section{HASIL DAN PEMBAHASAN}

\section{Kegiatan Pengelolaan Rumah Susun oleh Badan Pengelola.}

Rumah susun terdiri dari satuan rumah susun, bagian bersama, benda bersama dan tanah bersama. Satuan rumah susun adalah hak yang dimiliki oleh perseorangan dalam mengelola rumah susun miliknya sendiri. Selain itu, untuk bagian bersama, benda bersama dan tanah bersama adalah hak milik bersama, di mana hak ini dikelola bersama-sama oleh pemilik dan penghuni rumah susun tersebut. Oleh karena itu, di dalam pengelolaan terkait hak bersama ini seharusnya penerapan di lapangan tidak boleh tidak mengikuti aturan yang telah disepakati bersama. Hal ini dilakukan karena berkaitan dengan kepentingan publik atau orang banyak, bukan hanya untuk kepentingan pribadi atau pemilik dan penghuni rumah susun saja. Oleh sebab itu, hal ini telah diatur di dalam Bab VII Undang-Undang Nomor 20 Tahun 2011 Tentang Rumah Susun.

Sebenarnya pengaturan pengelolaan rumah susun sudah diatur di dalam Pasal 56 Ayat (1) Undang-Undang Nomor 20 Tahun 2011 Tentang Rumah Susun. Di dalam aturan sebut mengatur terkait dengan kegiatan operasional, pemeliharaan dan perawatan bagian bersama, benda bersama dan tanah bersama. Selain itu juga, dalam aturan ini ditegaskan bahwa dalam pengelolaan rumah susun wajib pengelolanya berbadan hukum. Hal ini sesuai dengan isi ketentuan pada pasal 56 Ayat (2) Undang-Undang Nomor 20 Tahun 2011 Tentang Rumah Susun. Namun, ketentuan ini tidak berlaku untuk semua rumah susun karena rumah susun umum sewa, rumah susun khusus dan rumah susun negara tidak termasuk dalam aturan tersebut. Untuk itu, di dalam melakukan pengelolaan rumah susun maka pengelola rumah susun baik rumah susun umum maupun rumah susun komersial harus berbadan hukum. Kondisi yang demikian juga diperkuat dengan adanya Pasal 56 Ayat (3) Undang-Undang Nomor 20 Tahun 2011 Tentang Rumah Susun dimana pengelola rumah susun yang berbadan hukum tersebut harus mendaftarkan dan dan mendapat izin usaha dari Bupati/Walikota atau Gubernur untuk DKI Jakarta.

Dalam pengelolaan rumah susun pastinya memerlukan biaya yang besar sehingga sudah seharusnya pihak pengelola rumah susun mendapatkan hak untuk menerima sejumlah biaya pengelolaan dari hasil kegiatan pengelolaan rumah susun tersebut. Biaya tersebut harus termasuk juga dalam biaya operasional, perawatan dan pemeliharaan rumah susun sehingga rumah susun tersebut terjaga dan terawat bangunannya sebab dalam melakukan operasional, perawatan dan pemeliharaan rumah susun mencapai biaya yang cukup besar. Terkadang pada kenyataannya di lapangan terjadi orang yang memiliki satuan rumah susun tersebut seringkali menyewa rumah susunnya kepada orang lain untuk dihuni Sehingga dalam hal ini pemilik dan penghuni satuan rumah susun berbeda. Selain itu, Pasal 57 ayat (2) Undang-Undang Nomor 20 Tahun 2011 Tentang Rumah Susun menentukan bahwa biaya pengelolaan dibebankan kepada pemilik dan penghuni secara proporsional, maksudnya adalah sesuai dengan nilai perbandingan proporsional atau jumlah unit yang menentukan besar proporsional biaya yang ditanggung oleh pemilik dan penghuni sarusun. Oleh karena itu, di dalam membantu masyarakat yang berpenghasilan rendah terkait dengan biaya pengelolaan rumah susun umum sewa dan rumah susun khusus milik pemerintah mendapatkan subsidi dari pemerintah.

Dalam praktek kita sering menjumpai beberapa pekerjaan di rumah susun seperti kebersihan, keamanan, pertamanan, dan pemeliharaan jaringan listrik dan telepon dialihkan (outsourcing) ke pihak lain. Hal ini tidak dilarang oleh undang-undang berdasarkan Pasal 58 Undang-Undang Nomor 20 Tahun 2011 tentang Rumah Susun yang menyebutkan bahwa dalam menjalankan kewajibannya "pengelola dapat bekerjasama dengan orang perseorangan dan badan hukum".

Pada prinsipnya di dalam melakukan pengelolaan rumah susun wajib melibatkan seluruh pemilik dan penghuni rumah susun tersebut sebab pengelolaan rumah susun berkaitan dengan kepentingan pemilik dan penghuni rumah susun itu sendiri. Pengelolaan rumah susun ini dilaksanakan melalui badan hukum yaitu Himpunan Pemilik dan Penghuni Satuan Rumah Susun. Namun, pada awalnya perhimpunan tersebut belum dibentuk menjadi badan hukum sehingga pelaku pembangunan berkesempatan untuk membangun rumah susun baik untuk umum maupun komersial dalam masa transisi sebelum adanya Pemilik dan Penghuni Satuan Rumah Susun. Masa transisi ini merupakan masa dimana satuan rumah susun yang belum terjual secara keseluruhan dan paling lama 1 tahun setiap penyerahan pertama kali rumah susun tersebut kepada pemiliknya.

Pelaku pembangunan dalam melakukan pengelolaan pada masa transisi pengelolaan pada masa transisi, pelaku pembangunan dapat bekerja sama dengan pengelola dan besarnya biaya pengelolaan rumah susun pada masa transisi ditanggung oleh pelaku pembangunan dan pemilik satuan rumah susun berdasarkan nilai perbandingan proporsional dari setiap satuan rumah susun. Ini berarti pelaku pembangunan juga wajib untuk menanggung biaya pengelolaan dari 
satuan rumah susun yang belum terjual. Namun dalam praktik sering dijumpai perhitungan biaya pengelolaan yang tidak transparan dan biaya pengelolaan untuk satuan rumah susun yang belum terjual ditanggung oleh pembeli/pemilik satuan rumah susun.

Pengelolaan rumah susun dilakukan oleh penghuni atau pemilik Rumah Susun tersebut karena sesuai dengan ketentuan Perhimpunan Penghuni rumah susun yang dituangkan dalam Anggaran Dasar dan Anggaran Rumah Tangga. Selain itu juga, koperasi PPPSRS memiliki peran juga sebagai badan pengelola rumah susun sehingga tidak harus Perhimpunan Pemilik Dan Penghuni Satuan Rumah Susun saja. Badan Pengelola yang dibentuk sendiri oleh PPPSRS harus dilengkapi dengan unit organisasi, personil, dan peralatan yang mampu untuk mengelola rumah susun. Badan Pengelola yang ditunjuk oleh penghuni harus mempunyai status badan hukum dan profesional. ${ }^{1}$

Dalam melakukan penyelenggaraan pembangunan rumah susun maka pengelola rumah susun memiliki waktu sekurang-kurangnya 3 bulan dan paling lama 1 tahun dari terbentuknya Perhimpunan Penghuni atas biaya penyelenggaraan pembangunan dalam melakukan pengelolaan rumah susun tersebut. Pada fakta yang terjadi seringkali ditemukan seperti petugas kebersihan, petugas keamanan, petugas menanam tanaman dan dan petugas pemeliharaan listrik serta telepon dialihkan ke pihak lain di dalam hal pengelolaan rumah susun.

Jika kondisi ini dilihat terkait dengan undang-undang yang berlaku maka sudah jelas bahwa perbuatan yang mengalihkan ke pihak lain sudah termasuk pelanggaran terhadap undang-undang tersebut. Hal yang demikian ini diatur di dalam Pasal 58 Undang-Undang Nomor 20 Tahun 2011 tentang Rumah Susun yang menentukan bahwa dalam menjalankan kewajibannya sebagaimana dimaksud dalam Pasal 56 ayat (2) pengelola dapat bekerjasama dengan orang perseorangan dan badan hukum. Jika isi pasal ini dikaitkan dengan fakta tersebut sudah jelas bahwa yang dapat melakukan kerjasama dengan pihak lain dalam pengelolaan rumah susun adalah pengelola yang telah berbadan hukum dimana pengelola tersebut memiliki kewenangan untuk mengelola rumah susun umum milik dan rumah susun komersial.

\section{Eksistensi Perhimpunan Pemilik dan Penghuni Satuan Rumah Susun (PPPSRS)}

Perhimpunan Pemilik dan Penghuni Satuan Rumah Susun (PPPSRS) merupakan suatu Organisasi yang ruang lingkupnya yaitu Rumah Susun baik berpenghuni maupun bukan berpenghuni, dimana organisasi ini mengatur dan mengurus serta mengelola kepentingan bersama dalam hal rumah susun. Untuk membentuk PPPSRS ini harus dibuat akta yang sah oleh Bupati atau Walikotamadya Kepala Daerah Tingkat II. Sedangkan untuk Perhimpunan penghuni Daerah Khusus Ibukota Jakarta disahkan oleh Gubernur Kepala Daerah Tingkat I. Dengan disahkannya Perhimpunan Penghuni tersebut maka organisasi ini dapat melakukan perbuatan hukum baik didalam maupun diluar pengadilan.

Pembentukan Perhimpunan Pemilik dan Penghuni Satuan Rumah Susun (disebut PPPSRS) adalah suatu kewajiban yang diberikan oleh Undang-Undang kepada Pemilik Sarusun yang diatur dalam Pasal 74 ayat (1) UndangUndang Nomor 20 Tahun 2011 tentang Rumah Susun. PPPSRS beranggotakan pemilik atau penghuni yang mendapat kuasa dari pemilik sarusun dan diberi kedudukan sebagai Badan Hukum berdasarkan Undang-Undang ini. Selaku badan hukum tententunya PPPSRS Memiliki ketentuan badan hukum sendiri karena setiap badan hukum mempunyai hak dan kewajiban yang diatur dalam AD/ART masing-masing sesuai dengan kebutuhannya dan badan hukum ini juga telah dilindungi oleh undang-undang yang berlaku. Oleh karena itu, Perhimpunan Penghuni Rumah Susun Yang telah mempunyai badan hukum dapat mewakilkan para penghuni atau pemilik satuan rumah susun ketika menyelesaikan perkara didalam maupun diluar pengadilan serta berkewenangan untuk mencapai ketertiban dan dan keamanan di lingkungan rumah susun tersebut.

Pengurus organisasi ini dipilih sesuai dengan asas kekeluargaan antara anggota perhimpunan penghuni rumah susun melalui Rapat Umum Perhimpunan Penghuni yang dilakukan demi mencapai keperluan organisasi tersebut. Dalam kepengurusan perhimpunan penghuni rumah susun ini sekurang-kurangnya terdiri atas ketua, sekretaris, bendahara dan dan seorang pengawas pengelolaan rumah susun. Dengan adanya anggota pengurus ini maka diharapkan akan dapat membentuk unit pengawasan pengelolaan rumah susun. Selain itu juga, apabila belum terbentuknya perhimpunan penghuni maka penyelenggara pembangunan berhak dan dapat bertindak sebagai pengurus perhimpunan sementara sehingga dapat membantu menyiapkan untuk terbentuknya perhimpunan penghuni dengan waktu yang tepat.

Apabila dilihat dalam subjek hukum maka anggota PPPSRS merupakan subjek hukum sehingga mempunyai hak untuk memakai, menyewa beli atau memfungsikan satuan rumah susun. Oleh karena itu, sebagai subjek hukum maka anggota perhimpunan penghuni rumah susun memiliki hak sebagai berikut :

1. Memilih dan dipilih menjadi pengurus dengan syarat yang ditentukan AD/ART.

2. Mengajukan usul dan pendapat dalam Rapat Umum.

3. Memanfaatkan dan menggunakan satuan Rusun sesuai peruntukannya.

${ }^{1}$ Erwin Kallo, Panduan Hukum Untuk Pemilik/Penghuni Rumah Susun (Kondominium, Apartemen dan Rusunami) (Jakarta: Minerva Athena Pressindo, Agustus 2008), hal 96 
Nuraini Zachman dan Nur Fauzia, Eksistensi Perhimpunan Pemilik dan Penghuni Satuan Rumah Susun (PPPSRS) dalam

4. Mendapatkan perlindungan sesuai AD/ART.

Sedangkan kewajiban dari anggota perhimpunan penghuni rumah susun adalah:

1. Mematuhi dan melaksanakan AD/ART, Tata Tertib yang diputuskan dalam Rapat Umum/Rapat Umum Luar Biasa atau yang ditetapkan oleh Rapat Pengurus.

2. Mematuhi segala peraturan yang berlaku yang dikeluarkan oleh Pemerintah Provinsi dan Pemkot/Pemkab.

3. Membayar kewajiban keuangan yang dipungut oleh Pengurus.

4. Memelihara, menjaga, mengatur, memperbaiki rusun dan lingkungannya atas Bagian bersama, Benda bersama dan Tanah bersama.

5. Menunjang terselenggaranya tugas-tugas pokok Pengurus dan Badan Pengelola.

6. Membina hubungan sesama anggota berdasarkan azas kekeluargaan dan norma-norma kehidupan Bangsa Indonesia.

7. Melaporkan kepada Pengurus PPPSRS, bila terjadi peralihan hak atas satuan rumah susun.

Tugas Pokok PPPSRS (Perhimpunan Penghuni Rumah Susun) adalah sebagai berikut:

1. Mengesahkan Anggaran Dasar dan Anggaran Rumah Tangga yang disusun oleh pengurus dalam Rapat Umum Perhimpunan Penghuni.

2. Membina Penghuni ke arah kesadaran hidup bersama yang serasi, selaras, seimbang dalam rumah susun dan lingkungannya.

3. Mengawasi pelaksanaan ketentuan-ketentuan yang tercantum dalam Anggaran Dasar dan Anggaran Rumah Tangga.

4. Menyelenggarakan tugas-tugas administratif penghunian.

5. Menunjuk atau membentuk dan mengawasi Badan Pengelola dalam pengelolaan rumah susun dan lingkungannya.

6. Menyelenggarakan pembukuan dan administrasi keuangan secara terpisah sebagai kekayaan perhimpunan penghuni.

7. Menetapkan sanksi terhadap pelanggaran yang telah ditetapkan dalam Anggaran Dasar dan Anggaran Rumah Tangga.

Pasal 56 Peraturan Pemerintah Nomor 4 Tahun 1988 mengatur mengenai Fungsi daripada Perhimpunan Penghuni, yaitu:

1. membina terciptanya kehidupan lingkungan yang sehat, tertib, dan aman.

2. mengatur dan membina kepentingan penghuni.

3. mengelola rumah susun dan lingkungannya.

Adapun ketertiban penghuni rumah susun telah disusun berdasarkan undang-undang rumah susun beserta peraturan yang berlaku lainnya dan mengikuti ketentuan-ketentuan teknis yang telah diberlakukan oleh perhimpunan pemilik dan penghuni satuan rumah susun demi untuk kepentingan pengelolaan rumah susun itu sendiri.

Selanjutnya setiap penghuni rumah susun mendapatkan hak atas rumah susun tersebut untuk dimanfaatkannya termasuk juga bagian bersama, Perda bersama dan tanah bersama sesuai dengan Anggaran Dasarnya. Untuk itu, setiap penghuni dilarang berbuat yang dapat membahayakan keamanan dan keselamatan penghuni lain, bangunan dan lingkungannya serta tidak boleh mengubah bentuk atau menambah bangunan yang tidak sesuai dengan kesepakatan bersama dengan perhimpunan penghuni rumah susun.

\section{Hak Suara Berkaitan dengan Kewenangan Pengelolaan}

Hak suara bagi Perhimpunan Pemilik dan Penghuni Satuan Rumah Susun (disebut PPPSRS) diatur dalam Pasal 77 ayat (1) Undang-Undang Nomor 20 Tahun 2011, disebutkan bahwa dalam hal PPPSRS memutuskan sesuatu yang berkaitan dengan kepemilikan dan pengelolaan rumah susun, setiap anggota mempunyai hak yang sama dengan NPP (Nilai Perbandingan Proporsional). Ayat (2) menyebutkan dalam hal PPPSRS memutuskan sesuatu yang berkaitan dengan kepentingan penghunian rumah susun, setiap anggota berhak memberikan satu suara.

Jika melihat dari penjelasan Arie S. Hutagalung yang pada intinya menjelaskan bahwa Ada tiga hak suara yang dimiliki oleh anggota perhimpunan penghuni rumah susun. Adapun ketiga hak suara tersebut yaitu hak suara penghuni, hak suara pengelola dan hak suara pemilik. ${ }^{2}$ Hak suara penghuni yaitu Hak yang dimiliki oleh semua anggota perhimpunan pemilik dan penghuni satuan rumah susun dalam menentukan terkait dengan tata tertib,

2 Arie S. Hutagalung, “Condominium dan Permasalahannya”, (Jakarta : Badan Fakultas Hukum Universitas Indonesia, 1998, hal 33-34 
penggunaan fasilitas bersama dan kewajiban dalam melakukan pembayaran iuran atas pengelolaan serta asuransi kebakaran terhadap korban kebakaran satuan rumah susun.

Kemudian hak suara pengelola sangat berperan penting dalam perhimpunan pemilik dan penghuni satuan rumah susun. Hak ini diperlukan dalam hal pemeliharaan, renovasi dan pembangunan sarana prasarana lingkungan rumah susun serta fasilitas umum yang telah diperhitungkan berdasarkan Nilai Perbandingan Proporsional (NPP) satuan rumah susun. Selanjutnya hak suara pemilih dalam hal ini mengatur tentang hubungan antara sesama penghuni satuan rumah susun, pemeliharaan pengurusan Rumah Susun dan biaya lain atas satuan rumah susun. Hak ini diperhitungkan dengan berdasarkan Nilai Perbandingan Proporsional atas satuan rumah susun.

Apabila dilihat pada kenyataan di lapangan maka penentuan hak suara anggota ini belum terwujud sepenuhnya sehingga menimbulkan ketidakadilan sebab rumah susun dalam satu tower masih ada juga kosong sehingga NPP dari pihak penyelenggara sangatlah besar, yang berimplikasi dengan pengelolaan rumah susun dikuasai oleh developer dikarenakan memiliki jumlah hak suara yang terbesar. Ketentuan demikian dianggap tidaklah adil.

Apabila dilihat dari kenyataan di lapangan maka sudah seharusnya pemerintah melakukan pemantauan terkait dengan perkembangan rumah susun karena hal ini ini merupakan sumber pemasukan pemerintah daerah dan dapat menciptakan lapangan pekerjaan terhadap orang yang bekerja sebagai buruh bangunan. Untuk itu, sudah seharusnya pemerintah memikirkan untuk membentuk lagi lembaga yang lebih spesifik dalam hal pengawasan kegiatan penyelenggaraan atau pengelolaan rumah susun tersebut. Selain itu juga, pemerintah harus merancang aturan yang lebih khusus terkait dengan pemisahan antara rumah susun hunian dengan rumah susun sewa. Hal demikian membuat pemerintah harus terlebih dahulu mengkaji berbagai macam aspek dan permasalahan dari setiap unsur stakeholder, termasuk juga dalam hal ini masyarakat sebagai penghuni dan organisasi Rumah Susun, praktisi yang berkaitan dengan pengelolaan rumah susun tersebut sehingga dalam penyusunan aturan hukum dengan rumah susun tidak lagi menimbulkan permasalahan. Dengan demikian, hak suara itu bergantung kepada siapa saja yang hadir dalam rapat perhimpunan penghuni rumah susun tersebut.

Pasal 77 ini dengan kedua ayatnya sering disalahgunakan interpretasinya untuk kepentingan pihak penyelenggara pembangunan rumah susun/developer dalam hal pengaturan pengelolaan rumah susun, yang menjadikan merekalah yang selalu keluar sebagai pihak yang berwenang untuk melaksanakan kegiatan pengelolaan rumah susun. Bayangkan pengertian "setiap orang mempunyai hak yang sama dengan NPP" berbeda dengan pengertian "setiap anggota berhak memberikan satu suara", padahal sesuatu yang berkaitan dengan kepemilikan dan pengelolaan rumah susun berkaitan dengan sesuatu yang berkaitan dengan kepentingan rumah susun. Hal inilah yang menjadi celah bagi penyelenggara pembangunan untuk mengambil alih pengelolaan dikarenakan kondisi masih banyaknya apartemen yang kosong dan belum terjual ketika dilakukan pengambilan suara atas siapa yang berwenang melakukan Pengelolaan, Hal inilah yang sering menimbulkan konflik antara penyelenggara pembangunan dan PPPSRS, jika Pasal ini tidak direvisi maka sampai kapanpun celah untuk menepiskan keberadaan PPPSRS sangatlah dimungkinkan, sehingga jelaslah tidak seimbang dimana ketidak seimbangan tersebut menimbulkan ketidak adilan.

Sehubungan dengan Pasal 77 ayat (1) dan ayat (2) Undang-Undang Nomor 20 Tahun 2011, hendaknya perlu di evaluasi kembali dikarenakan 2 ayat itu sangat kontradiktif dimana Developer menafsirkan dengan ayat (1) yaitu berdasarkan NPP, sedangkan PPPSRS menafsirkan dengan ayat (2) yaitu satu suara untuk setiap anggota, yang berarti setiap kepemilikan unit diwakili oleh satu suara walaupun satu orang itu mempunyai beberapa unit, misal 4 unit berarti 4 suara. Sehingga terhadap Pasal ini harus ada penegasan lebih lanjut agar tercipta rasa adil.

\section{Pengelolaan Rumah Susun Sewa dibandingkan dengan Pengelolaan Rumah Susun Komersial Pengelolaan Rumah Susun Sewa}

Pengelolaan rumah susun sewa membutuhkan beberapa komponen. Adapun beberapa komponen tersebut sebagai berikut:

1. Pengoperasian

Dalam pengoperasian tentu dibutuhkan sarana prasarana yang merupakan bagian dari pengelolaan teknis di lapangan. Dengan adanya sarana prasarana sehingga dapat merancang suatu pengoperasian dalam hal pemeliharaan dan perawatan rumah susun sewa. Hanya itu saja, terkait dengan monitoring dan evaluasi juga membutuhkan sarana prasarana pada setiap periode yang telah ditentukan dengan mempertimbangkan faktor efisien dan efektivitas serta selalu melakukan koordinasi kepada bagian pemasaran dan pembiayaan rumah susun sewa.

2. Pengorganisasian

Pengorganisasian ini terletak pada pengelolaan persewaan, pemasaran dan pembinaan penghuni rumah susun sewa. Pada bagian pengoperasian ini harus melakukan survei pemasaran dan dan melakukan penyusunan terkait dengan strategi pemasaran serta menjalankan sesuai dengan kebutuhan dalam satuan hunian dan satuan non hunian. Tidak hanya itu saja, dalam pengorganisasian ini harus saling berkoordinasi dengan bagian pengelolaan teknis dan pengelolaan administrasi terkait dengan hal pembiayaan.

3. Pembiayaan 
Dalam hal pengelolaan administrasi dan keuangan tentu merupakan bagian dari pembiayaan pengelolaan termasuk juga dalam hal ini pengelolaan rumah susun sewa. Untuk itu, pada bagian pembiayaan ini tentunya harus melakukan perencanaan terkait dengan anggaran biaya ya untuk tercapainya sistem pengoperasian yang baik. Selain itu juga, dalam pembiayaan ini dapat juga untuk menjalin kerjasama antar mitra dan juga melakukan pengelolaan administrasi terhadap kepegawaian dalam hal pengkajian atau memberi upah.

Apabila dilihat dari tiga komponen di atas maka komponen tersebut saling berhubungan antara satu dengan lainnya. Dalam pengelolaan rumah susun, ada beberapa pola pengelolaan rumah susun, sebagai berikut:

1. Pengelolaan Rumah Susun Sederhana Sewa

Pengelolaan rumah susun sederhana sewa merupakan salah satu upaya yang dilakukan pemerintah untuk memanfaatkan rumah susun sederhana sewa berdasarkan kebijakan penataan pemanfaatan, pembangunan, pengawasan dan pengendalian rumah susun sewa. Untuk melakukan pengelolaan rumah susun sederhana sewa maka harus ada perencanaan yang dipersiapkan untuk menyelenggarakan pengelolaan rumah susun sewa agar lebih baik dalam selenggarakannya. Perencanaan adalah suatu pemikiran dalam mengatasi permasalahan yang sedang dihadapi sehingga akan menimbulkan suatu hasil di masa yang akan datang.

Untuk itu, tujuan yang disasarkan dalam hal ini yaitu keinginan kolektif dan pengusahaan dalam keterpaduan antara kebijakan dan program kerja. Sebenarnya perencanaan membutuhkan pemikiran yang kritis sehingga pemikiran tersebut dapat diterima oleh masyarakat, untuk itu peran masyarakat sangat dibutuhkan dalam suatu perencanaan tersebut. Selain itu juga, dibutuhkan Unit Pengelolaan Teknis (UPT) dalam menjaga eksistensi rumah susun sederhana sewa ini sehingga setiap Unit Pengelolaan Teknis (UPT) mendapatkan perlindungan hukum terkait dengan hak dan kewajibannya di dalam Pasal 66 Peraturan Pemerintah Nomor 4 Tahun 1988 tentang Rumah Susun.

Model organisasi unit pengelola lokasi secara umum dibedakan dalam 2 (dua) model sebagai berikut :

a. Model swakelola yaitu pengelola operasional merupakan bagian dari organisasi pemilik atau yang mewakili pemilik rusunawa, yaitu Unit Pelaksana Teknis (UPT) atau badan usaha milik negara/daerah (BUMN/BUMD) atau perhimpunan penghuni/pemilik rusunawa atau perusahaan swasta pengembang rusunawa.

b. Model kerjasama operasional yaitu pengelolaan operasional merupakan pihak ketiga, terdiri dari konsultan properti, koperasi dan perhimpunan penguni, yang bermitra dengan pemilik/yang mewakili pemilik/pemegang hak pengelolaan aset rusunawa untuk melaksanakan tugas pengelolaan operasional rusunawa dalam jangka waktu yang ditentukan dan sesuai dengan peraturan yang berlaku.

Struktur organisasi unit pengelola lokasi atau unit pelaksana teknis dapat dikembangkan sesuai dengan kebutuhan organisasi dan lingkup pengelolaanya atau setidak-tidaknya mempunyai bidang-bidang yang mengelola administrasi dan keuangan, teknis serta persewaan, pemasaran dan pembinaan penghuni yang masing-masing dipimpin oleh seorang asisten manajer.

Badan pengelola ini dapat dibentuk dari perhimpunan penghuni untuk mengurus kepentingan bersama para pemilik dan penghuni serta mampu untuk membentuk badan pengelola yang memiliki tugas dalam menyelenggarakan pengelolaan yang meliputi pemeliharaan, perbaikan dan pengawasan terhadap penggunaan bagian bersama, benda bersama dan tanah bersama (UU No. 20/2011). Pembentukan perhimpunan penghuni disyahkan oleh Bupati atau Walikota.

Penghuni rumah susun mempunyai hak dan kewajiban sebagai berikut:

a. Penghuni/Penyewa mempunyai hak-hak sebagai berikut:

1) Menempati rusunawa untuk keperluan tempat tinggal

2) Menggunakan fasilitas umum dan fasilitas sosial dalam lingkungan rumah susun sederhana sewa

3) Mengajukan keberatan atas pelayanan yang kurang baik oleh pengelola

4) Mendapat penjelasan, pelatihan dan bimbingan terhadap pencegahan, pengamanan dan penyelamatan terhadap bahaya kebakaran.

b. Kewajiban penghuni/penyewa adalah sebagai berikut :

1) Membayar sewa dan segala iuran yang ditetapkan sesuai dengan ketentuan yang berlaku.

2) Membayar rekening listrik dan air bersih sesuai ketentuan.

3) Membuang sampah setiap hari di tempat yg ditentukan

4) Memelihara sarana rumah susun yang disewa dengan sebaik-baiknya.

5) Mematuhi ketentuan tata tertib tinggal di rumah susun sederhana sewa.

Selain mempunyai hak dan kewajiban dalam memanfaatkan barang yang bersifat pribadi, penghuni juga mempunyai hak atas barang bersama, benda bersama dan tanah bersama yang merupakan fasilitas dari rumah 
susun yang diatur dengan Undang-Undang Nomor 20 Tahun 2011 tentang Rumah Susun berlaku atas sarana rumah susun yang dimiliki oleh perseorangan atau badan hukum.

Dalam kegiatan operasional dan pemeliharaan rumah susun sederhana sewa ini, badan pengelola rumah susun sederhana sewa wajib melaporkan kepada pemilik aset rumah susun sederhana sewa dan Pemerintah Daerah Kabupaten/Kota. Untuk melakukan pemantauan dalam kegiatan operasional dan pemeliharaan itu maka dibutuhkan badan pengawas, dimana badan pengawas ini berwenang untuk mengawasi penyelenggaraan rumah susun sederhana sewa.

2. Pengelolaan Pola Unit Pelaksana Teknis

Unit Pelaksana Teknis ini dibentuk berdasarkan Perda setempat atau keputusan Walikota/Bupati serta Kepmen PU. Unit Pelaksana Teknis (UPT) ini adalah suatu unit yang terbentuk setelah selesai proses pembangunan sampai dengan serah terima rumah susun sederhana sewa tersebut. Selain itu juga, kegiatan operasi dan pemeliharaan rumah susun sederhana sewa ini wajib dilaporkan kepada Badan Pengelola kepada Pemilik Aset Rusunawa dan Pemda/Pemkot secara berkala.

Kemudian terkait dengan pelarangan terhadap penghuni rumah susun sederhana sewa apabila dilihat dari administrasi seperti memindahkan hak sewa dan mengisi rumah susun sederhana sewa, dalam hal huni rumah susun sederhana sewa berbeda dengan aturan atau kesepakatan dalm kontrak. Jika dari sisi fasilitas maka penghuni rumah susun sederhana sewa dilarang untuk melakukan kerusakan fasilitas rumah susun, tidak boleh mengubah instalasi tanpa izin pengelola, menjemur tidak mengikuti tempat yang telah ditentukan, memelihara binatang peliharaan (kecuali ikan), menyimpan/ meletakkan barang di koridor.

Apabila larangan tersebut dilanggar oleh penghuni rumah susun sederhana sewa maka penghuni akan dikenakan sanksi berupa putusnya kontrak yang dilakukan oleh sepihak dan uang jaminan atas rumah susun sederhana sewa tersebut akan hilang jika penghuni baru melakukan pembayaran selama 3 bulan secara berturutturut wajib serta keluar dari rumah susun sederhana sewa.

3. Pengelolaan Pola Perumnas (PMP)

Pengelolaan dengan pola kerjasama antara Perumnas dengan Pemda DKI misalnya, penetapan penghuni rusunawa dapat mengikuti program yang ditetapkan Pemda DKI. Besaran sewa rusunawa yang dikelola Perumnas harus mengikuti ketentuan yang berlaku. Mengingat target group penyediaan rusunawa adalah masyarakat berpenghasilan menengah ke bawah, maka biaya sewa yang ditetapkan tidak dapat lebih besar dari 1/3 upah minimum regional (UMR). Pada beberapa kota, besar sewa maksimum ditetapkan oleh Gubernur Kepala Daerah Tk. I. Besar sewa yang ditetapkan di luar biaya penggunaan listrik, air dan gas dan sampah. Biaya yang sudah tercakup di dalam biaya sewa bulanan adalah hak penggunaan unit, biaya pemeliharaan fasilitas dan utilitas, biaya keamanan dan pemeliharaan lingkungan.

Kewenangan pengelola rumah susun dalam membuat suatu kebijakan harus mengikuti peraturan setiap daerah terkait dengan rumah susun sederhana sewa. Kebijakan yang dapat dilakukan yaitu terkait dengan besaran sewa setiap bulan pada setiap unit hunian, besaran pembayaran iuran untuk keamanan dan kebersihan rumah susun sederhana sewa, menentukan sanksi terhadap siapa saja yang melakukan pelanggaran aturan tersebut, menjalankan ketertiban, melaksanakan inspeksi mendadak sampai dengan memberikan sanksi, penalti bahkan melakukan pemutusan atau pengeluaran atau pemberhentian hak huni rumah susun sederhana sewa jika telah terjadi pelanggaran aturan yang telah berlaku dimana telah dilakukan oleh penghuni rumah susun sederhana sewa.

Pengelola rumah susun sederhana sewa memiliki kewajiban yaitu melakukan persediaan, memelihara, mengelola dan menjaga kualitas utilitas serta fasilitas lingkungan rumah susun sederhana sewa. Selain itu juga, pengelola rumah susun sederhana sewa mengembalikan uang jaminan sewa jika telah diputus kontraknya sesaui dengan aturan yang berlaku dalam hal rumah susun sederhana sewa.

Operasi dan Pemeliharaan, Perumnas di bawah Kementerian BUMN menanggung seluruh biaya operasional harian rutin rumah susun, biaya pemeliharaan dan biaya perbaikan serta biaya yang dikeluarkan sebagai akibat dari pembayaran honorarium dan gaji pegawai.

4. Pengelolaan Pola Kemitraan dengan Swasta

Pola kemitraan ini mengacu pada Peraturan Pemerintah Nomor 44 tahun 1997 mengenai kemitraan. Kemitraan adalah kerjasama usaha antara usaha kecil dengan usaha menengah dan atau dengan usaha besar yang disertai pembinaan dan pengembangan oleh Usaha Menengah dan atau Usaha Besar dengan memperhatikan prinsip saling memerlukan, saling memperkuat dan saling menguntungkan.

Pola ini dilakukan karena berhubungan dengan usaha yang dilakukan melalui pola-pola yang telah disesuaikan dengan sifat dan tujuan dari usaha yang dimitrakan dengan memberikan peluang terhadap kemitraan secara meluas kepada usaha kecil, oleh Pemerintah dan dunia usaha. 


\section{Pengelolaan Rumah Susun Komersial}

Pasal 59 Undang-Undang Nomor 20 Tahun 2011 tentang Rumah Susun menyebutkan bahwa Pelaku pembangunan yang membangun Rumah Susun umum milik dan Rumah Susun komersial dalam masa transisi sebelum terbentuknya PPPSRS wajib mengelola Rumah Susun. Ayat (2) menyebutkan Masa transisi sebagaimana dimaksud pada ayat (1) ditetapkan paling lama 1 (satu) tahun sejak penyerahan pertama kali sarusun kepada pemilik, dan Pelaku pembangunan dalam pengelolaan Rumah Susun sebagaimana dimaksud pada ayat (1) dapat bekerja sama dengan pengelolaan. Besarnya biaya mengelola Rumah Susun pada masa transisi sebagaimana dimaksud pada ayat (1) ditanggung oleh pelaku pembangunan dan pemilik sarusun berdasarkan NPP setiap sarusun. Pasal 60 ayat (1) Ketentuan lebih lanjut mengenai pengelolaan Rumah Susun, masa transisi, dan tata cara penyerahan pertama kali sebagaimana dimaksud dalam Pasal 56, Pasal 57, Pasal 58, dan Pasal 59 diatur dengan peraturan pemerintah.

Kedua aturan tersebut dengan jelas menentukan bahwa Badan Pengelola Rumah Susun Komersial adalah PPPSRS, sedangkan developer sebagai Badan Pengelola sementara. Pasal 74 ayat (3) menyebutkan bahwa PPPSRS diberi kedudukan sebagai badan hukum, dan dalam Pasal 75 ayat (2) menyebutkan bahwa dalam hal PPPSRS telah terbentuk, pelaku pembangunan segera menyerahkan pengelolaan benda bersama, bagian bersama dan tanah bersama kepada PPPSRS. Pengelolaan Rusun dapat dilakukan oleh suatu badan pengelola yang ditunjuk atau dibentuk sendiri oleh PPPSRS (Koperasi PPPSRS dapat berperan sebagai Badan Pengelola).

\section{SIMPULAN}

1. Kegiatan Pengelolaan Rumah Susun oleh Badan Pengelola adalah pengelolaan rumah susun wajib pengelolanya berbadan hukum yaitu Himpunan Pemilik dan Penghuni Satuan Rumah Susun. Pelaku pembangunan dalam melakukan pengelolaan pada masa transisi pengelolaan ketika Himpunan Pemilik dan Penghuni Satuan Rumah Susun belum dibentuk. Namun, pada faktanya dalam kegiatan pengelolaan rumah susun ini seringkali dialihkan ke pihak lain oleh pengelolaan rumah susun.

2. Eksistensi Perhimpunan Pemilik dan Penghuni Satuan Rumah Susun (PPPSRS) adalah Perhimpunan Pemilik dan Penghuni Satuan Rumah Susun harus dibuat akta yang sah oleh Bupati atau Walikotamadya Kepala Daerah Tingkat II. Sedangkan untuk Perhimpunan penghuni Daerah Khusus Ibukota Jakarta disahkan oleh Gubernur Kepala Daerah Tingkat I sehingga mempunyai hak untuk memakai, menyewa beli atau memfungsikan satuan rumah susun.

3. Hak Suara Berkaitan dengan Kewenangan Pengelolaan adalah penentuan hak suara anggota ini belum terwujud sepenuhnya sehingga menimbulkan ketidakadilan sebab rumah susun dalam satu tower masih ada juga kosong sehingga NPP dari pihak penyelenggara sangatlah besar, yang berimplikasi dengan pengelolaan rumah susun dikuasai oleh developer dikarenakan memiliki jumlah hak suara yang terbesar.

4. Pengelolaan Rumah Susun Sewa dibandingkan dengan Pengelolaan Rumah Susun Komersial adalah pengelolaan rumah susun sederhana sewa dibutuhkan Unit Pengelolaan Teknis (UPT) dan badan pengelola rumah susun sederhana sewa wajib melaporkan kepada pemilik aset rumah susun sederhana sewa dan Pemerintah Daerah Kabupaten/Kota, sedangkan Pengelolaan Rumah Susun Komersial adalah Badan Pengelola Rumah Susun Komersial adalah Perhimpunan Pemilik dan Penghuni Satuan Rumah Susun, developer sebagai Badan Pengelola sementara. Pelaku pembangunan segera menyerahkan pengelolaan benda bersama, bagian bersama dan tanah bersama kepada Perhimpunan Pemilik dan Penghuni Satuan Rumah Susun.

\section{DAFTAR PUSTAKA}

Kallo, Erwin, Panduan Hukum Untuk Pemilik/Penghuni Rumah Susun (Kondominium, Apartemen dan Rusunami), (Jakarta : Minerva Athena Pressindo), 2008.

Hutagalung, Arie S, Condominium dan Permasalahannya, (Jakarta : Badan Fakultas Hukum Universitas Indonesia), 1998. 